\title{
Surgery or surgical defolation in 'Grand Naine' banana in the control of black Sigatoka in the state of Rio de Janeiro
}

\begin{abstract}
Jose Leonardo Santos Jiménez ${ }^{1} \&$ Paulo Sergio Torres Brioso ${ }^{2}$
Abstract -'Grande Naine' banana (Musa acuminata - AAA) in the municipality of Angra dos Reis (RJ) has been affected by the Black Sigatoka agent, Mycosphaerella fijiensis (current name Pseudocercospora fijiensis); causing losses to local producers, mostly small producers and low-income producers. Since Black Sigatoka was reported in the mentioned municipality, it was aimed to determine control efficiency through surgical measurement or surgical defoliation and to evaluate its effect on banana productivity characteristics. For this purpose, treatment was designed in the form of completely randomized blocks containing three blocks, each block with five plants with treatment (Surgery) and five plants without treatment (Control), in a total of 30 plants with fungal infection. Treatments were performed every 15 days with monthly severity assessments (Weighted Mean of Infection - MPI) by the method of Stover modified by Gauhl. The results obtained at the end of the trial showed significant differences in all variables (Severity, youngest leaf spotted, bunch weight and fruit size), and treatment with surgery provided reduction in severity (MPI) around 58\%, thus confirming that plants received adequate treatment according to the results obtained for this methodology, and, contributing to the increase of the healthy leaf area in the youngest leaves, whereas in plants without surgery (Control), severity increased by $14.8 \%$ in comparison to the initial MPI evaluation, consequently having a smaller healthy leaf area for the accomplishment of photosynthesis and other physiological processes. In production variables bunch weight, fruit size and number of fruits, differences were significant $(\operatorname{Pr}>\mathrm{F}=$ 0.0001 ), reaching an increase in yield of up to $300 \%$ when compared to Control. It is therefore an effective method for the control of phytopathogen black sigatoka unpublished in the state of Rio de Janeiro and that will bring direct benefits for Family Agriculture in the region of incidence of this banana disease.
\end{abstract}

Index terms: Musa acuminata, Mycosphaerella fijiensis, Pseudocercospora fijiensis, Control.

\section{Corresponding author:} jose-111@hotmail.com

Received: October 31, 2017. Accepted: January 29, 2018.

Copyright: All the contents of this journal, except where otherwise noted, is licensed under a Creative Commons Attribution License.

\section{(cc) $\mathrm{E} Y$}

\section{Cirurgia ou desfolha cirúrgica em bananeira}

\section{'Grande Naine' no controle da Sigatoka-Negra, no Rio de Janeiro}

\begin{abstract}
Resumo-A bananeira (Musa acuminata - AAA) 'Grande Naine', no município de Angra dos Reis (RJ), tem sido afetada pelo agente da Sigatoka-Negra, Mycosphaerella fijiensis (atualmente denominado de Pseudocercospora fijiensis), ocasionando perdas aos produtores locais em sua maioria pequenos produtores e de baixa renda. Uma vez que a Sigatoka-Negra foi assinalada no município citado, objetivou-se determinar a eficácia do controle através de medida de Cirurgia ou Desfolha Cirúrgica; e avaliar o efeito desta sobre as caraterísticas de produtividade da bananeira. Para tal finalidade, foi idealizado na forma de blocos inteiramente casualizados, contendo três blocos, e cada bloco tinha cinco plantas com tratamento (Cirurgia) e cinco plantas sem tratamento (Controle), num total de 30 plantas com infecção fúngica. A cada 15 dias, foram feitos os tratamentos, com avaliações mensais da severidade (Média Ponderada da Infecção - MPI), pelo método de Stover modificado por Gauhl. Os resultados obtidos ao final do ensaio evidenciaram diferenças significativas em todas as variáveis (Severidade, folha mais jovem doente, peso e tamanho dos cachos) avaliadas, sendo que o tratamento com Cirurgia proporcionou redução da severidade (MPI) em torno de 58\%, confirmando assim que as plantas receberam um tratamento adequado, segundo resultados obtidos para esta metodologia, e contribuindo com o aumento da área foliar sadia nas folhas mais jovens da planta, enquanto nas plantas sem a Cirurgia (Controle) a severidade aumentou $14,8 \%$ em comparação com a avaliação inicial do MPI, e por consequência tendo menor área foliar sadia para a realização da fotossíntese e dos demais processos fisiológicos da planta. Nas variáveis da produção, para o peso dos cachos, número e tamanho dos frutos, as diferenças foram significativas $(\operatorname{Pr}>\mathrm{F}=0,0001)$, chegando a ter um aumento no rendimento de até $300 \%$, quando comparado com o Controle. Trata-se, portanto, de um método eficaz de controle para o fitopatógeno da sigatoka-negra, inédita no Estado do Rio de Janeiro, e que trará benefícios diretos à Agricultura Familiar para a região de incidência dessa doença em bananeira.
\end{abstract}

Termos para indexação: Musa acuminata, Mycosphaerella fijiensis, Pseudocercospora fijiensis, Controle. 


\section{Introduction}

Banana is a very important culture in the world, being cultivated in more than 100 countries. The largest world's banana producer is India, followed by China, the Philippines and Brazil, the latter with production of 6.7 million tones (FAOSTAT, 2016). In Brazil, the main cultivars are: Prata, Prata Anã, Pacovan, Nanica, Nanicão and Grande Naine.

Banana farming in the State of Rio de Janeiro has great economic and social importance in and has great exploitation potential. According to IBGE (2016), in Rio de Janeiro, banana production is 142,917 tons in a harvested area of 20,774 hectares, with average yields of 6.9 tons per hectare. It is important to highlight that most banana farmers occupy areas between two and five hectares (WILKINSON et al., 2012). The municipality of Angra dos Reis is the largest producer in the southern state of Rio de Janeiro, with production of 2,600 tons of banana in an area of 650 hectares (IBGE, 2016).

One of the phytosanitary problems of banana crop is black sigatoka and yellow sigatoka, caused by fungi Mycosphaerella fijensis M. Morelet (1969) [currently called Pseudocercospora fijiensis (M. Morelet) Deighton, 1976] and M. musicola, respectively, the former being more aggressive. In 2013, the presence of black sigatoka was found for the first time in the state of Rio de Janeiro, which is difficult to control, attacking almost all commercial varieties. Black sigatoka is the main loss factor in banana productivity, with reductions of up to $100 \%$ in commercial banana production of susceptible cultivars. If no control measures are adopted, black sigatoka may replace yellow sigatoka in an area over a period of four years, and may quadruple the number of fungicide applications, as occurred in Central America (OROZCO-SANTOS, 1998; MARIN et al. al., 2003).

Cultural practices are among control measures and of these, Surgery or Surgical Defoliation stands out. However, this technique has not been recommended because there are no studied in literature that provide technical and economic support for this practice (GASPAROTTO et al., 2006). The management of this disease has been carried out with the application of fungicides associated with cultural alternatives such as defoliation. However, the culture in the state of Rio de Janeiro is represented by family farming and small producers who do not have sufficient resources to make chemical control. Thus, surgery was implemented in the city of Angra dos Reis, which consists of the total or partial elimination of affected leaves. The management of foliar tissue, with the presence of the fungus, is important to reduce pathogen sporulation over time. The purpose of this practice is to totally or partially eliminate the affected plant tissue and along with it the fungus propagules. Diseased leaves left in the plant show the highest production and discharge of $M$. fijiensis ascospores, which can survive and be released for more than 20 weeks (GAUHL, 1994). In leaves deposited in the soil, the pathogen survives from three to six weeks (GUZMÁN; ROMERO, 1995; VILLALTA; GUZMÁN, 2005). The total or partial cut of leaves depends on the degree of severity in leaves, if infection is partial and is not greater than $40-50 \%$ of the affected leaf area, it is suggested to cut or to perform the surgery of the affected tissue (OROZCO-SANTOS et al., 2008). However, if the degree of infection is greater than $50 \%$, the entire leaf should be eliminated.

The aim of this study was to evaluate the effect of surgery on banana leaves on the severity of black sigatoka and on banana productivity in the municipality of Angra dos Reis (Rio de Janeiro, Brazil).

\section{Material and Methods}

This research was carried out in the municipality of Angra do Reis, district of Ariro, located to the southern state of Rio de Janeiro. The municipality has tropical climate, with significant rainfall. The average annual temperature is $23.2^{\circ} \mathrm{C}$ and the mean rainfall is $1975 \mathrm{~mm}$ (INMET, 2016).

The experiment was established in a plantation area with 'Grande Naine' banana (Musa acuminata - AAA) aged 4-5 years, using 30 banana plants at four months of age and with the presence of the black sigatoka agent $M$. fijiensis in leaves.

In order to confirm the disease in the field, leaf samples of 'Grande Naine' banana with black sigatoka lesions were collected, packed in paper bags, sealed, packed in ice and sent to the Official Laboratory of Phytosanitary Diagnosis of UFRRJ, where procedures were performed to confirm the causal agent in Stereoscopic and Optical Microscopy, fungal isolation in BDA culture medium, extraction of fungal DNA followed by PCR test with ACTR / MFactF primers for M. fijiensis, as recommended by Brioso and Gasparotto (2012).

The experimental design was completely randomized blocks with three replicates, where each block had five plants with treatment (Surgery) and five plants without treatment (Control), with a total of 30 plants. Treatment was performed every 15 days from April to December 2016. It should be noted that during the experimental period, three weed controls were carried out throughout the area. The practice of eliminating the "heart" at the time of development of bunches in the 30 experimental plants was also performed. No other management practice such as fertilization, pest control, thinning during the conduction of the experiment was performed.

Surgery was performed in each plant with the presence of symptoms of the disease. After treatment in 
each plant, the cutting tool was disinfected with $0.25 \%$ sodium hypochlorite. Treatment consisted of eliminating leaves with more than $50 \%$ of symptoms, while those with less than $50 \%$ of symptoms, only the affected part was eliminated and $16 \%$ of leaf number 3 was also eliminated (from top to low), even asymptomatic, thus allowing the elimination of potentially infectious foliar tissue, avoiding the production and release of fungal ascospores.

The Weighted Mean of Infection - MPI (Severity) of plant disease was monthly evaluated according to the Stover methodology modified by Gauhl (1989), in which the total area covered by the disease in plants was visually evaluated by means of a scale composed by six infection degrees (Table 1). All leaves present, except for old and injured leaves (leaves dried or dead by the disease) were evaluated. The youngest leaf spotted (YLS) per plant was also evaluated, which is the youngest leaf from top to bottom with the presence of symptoms of the disease, and is usually the first symptoms of the infection (Grade 1 - up to 10 spots). MPI helps to determine the severity of the disease in the area where the banana tree is, and its value should be two or less in crops with adequate management. At the time of harvest, productivity characteristics such as bunch weight (kg), fruit size number and of fruits (length and diameter in centimeters) were evaluated.

Statistical analysis was performed using SAS software (Statistical Analysis System, SAS Institute), version 9.3. Data were submitted to analysis of variance (ANOVA). The comparison of means of treatment with surgery and control was performed by the test $\mathrm{F}$.

\section{Results and Discussions}

At the beginning of the experiment, the incidence of M. fijiensis was $100 \%$ in banana trees, since all plants had symptoms of black sigatoka. From the beginning to the end of trial, the presence of the fungus was always observed in plants, and the fungus was less present in plants treated with surgery from the first month of treatment.

The severity of the fungus using MPI values at baseline was 2.7 for treatment (with Surgery) and Control (Figure 1). This value decreased considerably month by month in plants treated with Surgery, obtaining in the last evaluation of the trial (Flowering of plants) value of 1.3 for treatment (with Surgery), achieving reduction of $58 \%$ in severity, being a very good indicator for the development of plants and fruits. In control, the value increased little by little, remaining constant until reaching flowering with very high severity levels (3.1) of this disease, resulting in a $14.8 \%$ increase in severity when compared to treatment (Surgery). The results obtained for this variable were highly significant, being in agreement with results obtained by Villalta and Guzmán (2006), who concluded that with the detailed Sanitary Defoliation (Thinning and Surgery), at weekly intervals, it was possible to reduce the disease severity. Merchán and Chavarriaga (1994) demonstrated that with the practice of Surgery, black sigatoka can be maintained at low levels of infection. Surgery and soil accumulation of eliminated leaves significantly reduced leaf area exposed to ascospore discharge and decreased up to $80 \%$ inoculum production potential and black sigatoka severity (OROZCO-SANTOS et al., 2002).

Table 1. Severity classification according to Stover methodology modified by Gahul (1989).

\begin{tabular}{cc}
\hline Degree & Leaf Damage Description \\
\hline $\mathbf{1}$ & Up to 10 spots per leaf \\
$\mathbf{2}$ & Less than $5 \%$ of diseased leaf area \\
$\mathbf{3}$ & $6-15 \%$ of diseased leaf area \\
$\mathbf{4}$ & $16-33 \%$ of diseased leaf area \\
$\mathbf{5}$ & $34-50 \%$ of diseased leaf area \\
$\mathbf{6}$ & More than $50 \%$ of diseased leaf area \\
\hline
\end{tabular}




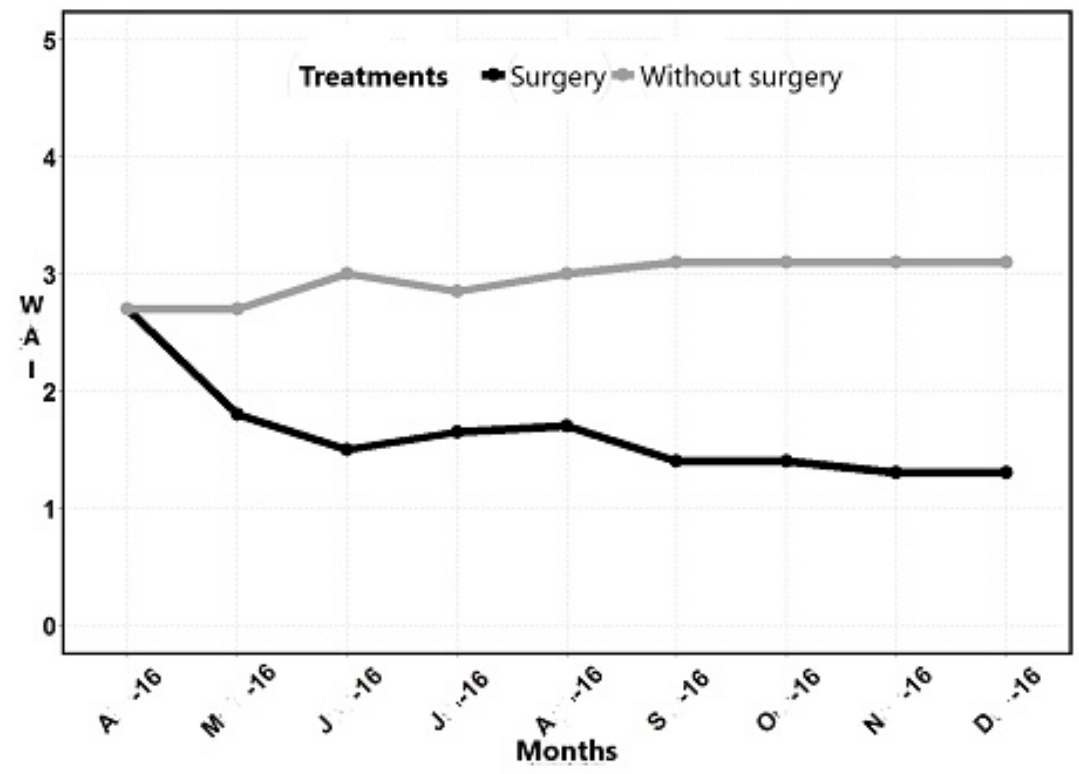

Figure 1. Effect of Surgery on severity - Weighted Mean of Infection (MPI) of black sigatoka in 'Grande Naine' (Musa acuminata - AAA) banana plants from April to December. Angra dos Reis, RJ. 2016.

In the YLS variable, it was observed that the differences between treatments were significant (Figure 2), since YLS in treatment was increased as surgery was performed, obtaining 4-5 new and asymptomatic leaves per plant; therefore, treated plants presented more healthy leaf area, thus obtaining more functional leaves, making greater photosynthetic process, which was beneficial for the development of bunches and fruits, while in control, the presence of the fungus was verified from leaf number 2 ; therefore, these plants presented less amount of healthy leaf area, affecting the development and weight of bunches, according to FAO research (LEHMANN-DANZINGER, 1984), which concluded that higher number of young leaves without fungus symptoms corresponds to lower problems in the production of bunches. The differences between treatment with and without Surgery were very visible since it was possible to obtain more than $60 \%$ healthy leaf area in young leaves per plant with Surgery, whereas in Control, the percentage of healthy leaf area was only about $20 \%$.

According to the analysis of variance, variables bunch weight, fruit size and number of fruits (length and diameter) indicated significant statistical differences between treatments with Surgery and control; $\mathrm{Pr}>\mathrm{F}=$ 0.0001 (Table 2). Regarding bunch weight, significant differences were observed, since the average of treated plants was $13.33 \mathrm{~kg}$.plant ${ }^{-1}$, while the average of plants without treatment was $3.32 \mathrm{~kg}$ plant $^{-1}$ (Figure 3 -I). In this case, surgery generated an increase in production of up to $300 \%$, probably due to the greater leaf area available in plants to develop and perform all physiological processes such as light uptake, energy and photosynthesis. In control, there was a reduction in bunch weight of approximately $75 \%$, due to the smaller leaf area for photosynthesis. This is very important for the development of bunches.
According to Rodriguez and Cayón (2008), as the severity of disease symptoms increases, leaf photosynthesis decreases, affecting bunch development, weight and size. For variable number of fruits, if significant differences were obtained, the mean number of fruits with treatment was 104.66 per bunch; while the mean of control was 36.50 per bunch (Figure 3-II), resulting in an increase of $187 \%$ more fruits when compared to control.

For fruit size, differences were significant; the mean length was $15 \mathrm{~cm}^{\text {fruit }}{ }^{-1}$ for treatment with surgery, and $11.44 \mathrm{~cm} \mathrm{fruit}^{-1}$ for control (Figure 3-III), achieving 31\% increase in fruit length of treated plants, when compared to control. For diameter, treatment was $3.89 \mathrm{~cm} \mathrm{fruit}^{-1}$ and for control, diameter was $3.28 \mathrm{~cm} /$ fruit (Figure 3-IV), increasing this characteristic in the treatment with surgery by $18.6 \%$.

Productivity characteristics in the experiment agree with results obtained in banana "Figo" variety (Musa AAB) by Barrera et al. (2008), who concluded that the bunch characteristics are significantly affected by the exposure of functional leaves, and plant must have at least six functional leaves for better fruit development. These authors confirmed that fruit development is a product of the flow of carbohydrates from photosynthesis of leaves. It should be taken into account that leaves are the organs that are directly involved in fruit development and are those that produce photoassimilates that are later translocated to the bunch (MARTIN; CHARPENTLER, 1963). According to Silva et al. (2000), the greater number of leaves in the inflorescence emission suggests that the bunch may have better conditions for its development, evidencing this affirmation in results obtained in this study.

Although significant differences in productivity variables are observed, the results were more marked in bunch weight and number of fruits. In size variables, 
they were not so marked, perhaps because during the experiment, no fertilization was performed, as well as the practice of thinning of leaves, agreeing with Rodríguez et al. (1988), where it was established that the practice of thinning is understood as the elimination of several "bunches", so that dry matter not commercially usable is distributed among hands that remain in the bunch, causing an increase in fruit size.
It is worth mentioning that in order to obtain better production in this banana cultivar, it is recommended to make an integrated management and agronomic practices, from the purchase of indexed seedlings, crop establishment up to harvest, allied to Surgery in areas with black sigatoka in order to reduce damages caused by this disease and contribute to increase productivity.

Table 2. Significance and analysis of variance of treatments for the study variables.

\begin{tabular}{cccccc}
\hline & Item & Num DF & Den DF & F Value & Pr $>$ F \\
\hline Weight & Treatment & 1 & 25 & 315.61 & $<.0001$ \\
Fruits & Treatment & 1 & 25 & 113.33 & $<.0001$ \\
Length & Treatment & 1 & 26 & 57.4 & $<.0001$ \\
Diameter & Treatment & 1 & 26 & 31.15 & $<.0001$ \\
\hline
\end{tabular}

${ }^{1}$ Num DF $=$ Degrees of Freedom; Den DF $=$ Sum of mean squares; F Value $=$ F calculated

* Significant differences - $\operatorname{Pr}>\mathrm{F}=0.0001$.

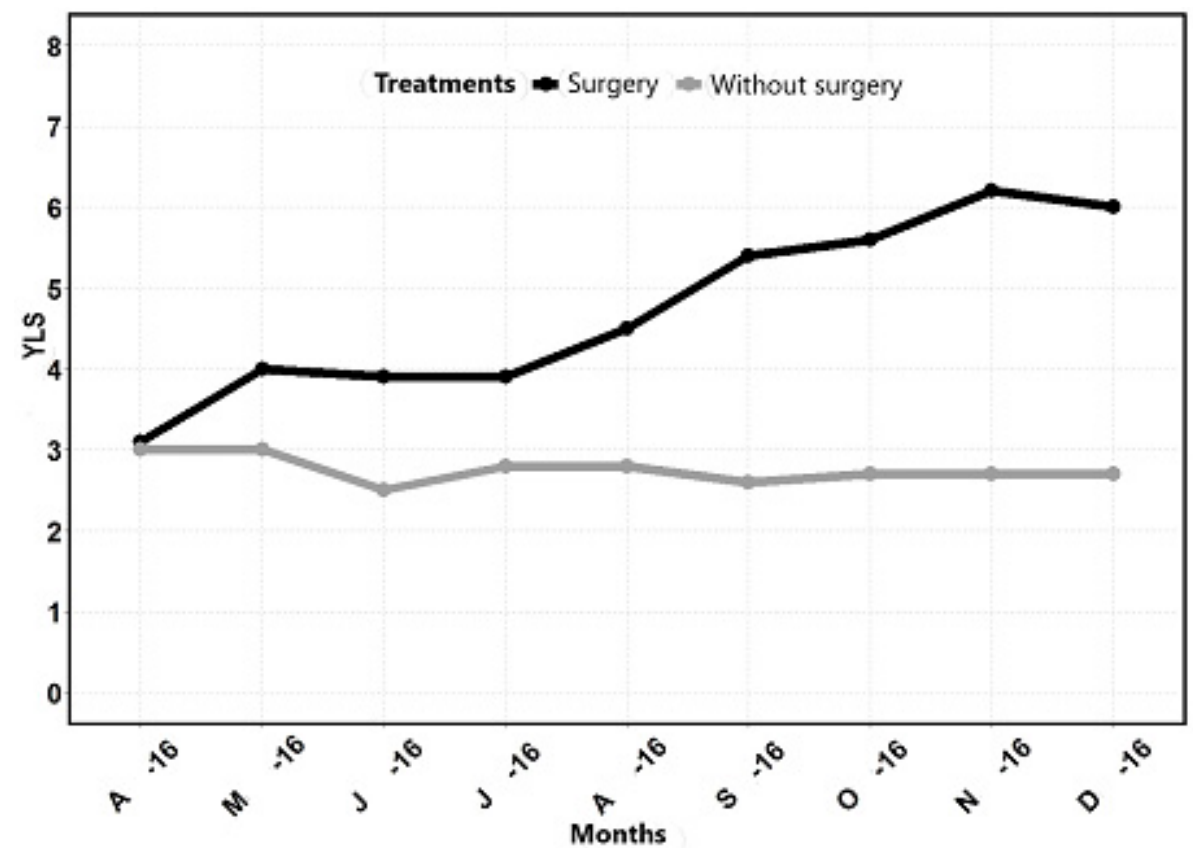

Figure 2. Effect of Surgery on youngest leaf spotted (YLS) in 'Grande Naine' (Musa acuminata - AAA) banana plants infected with black sigatoka from April to December. Angra dos Reis, RJ. 2016. 


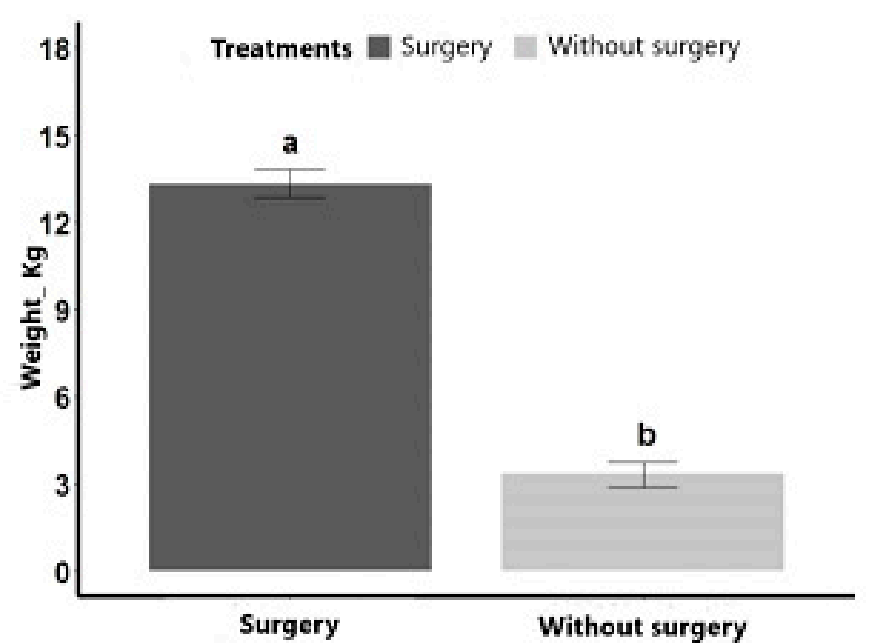

III

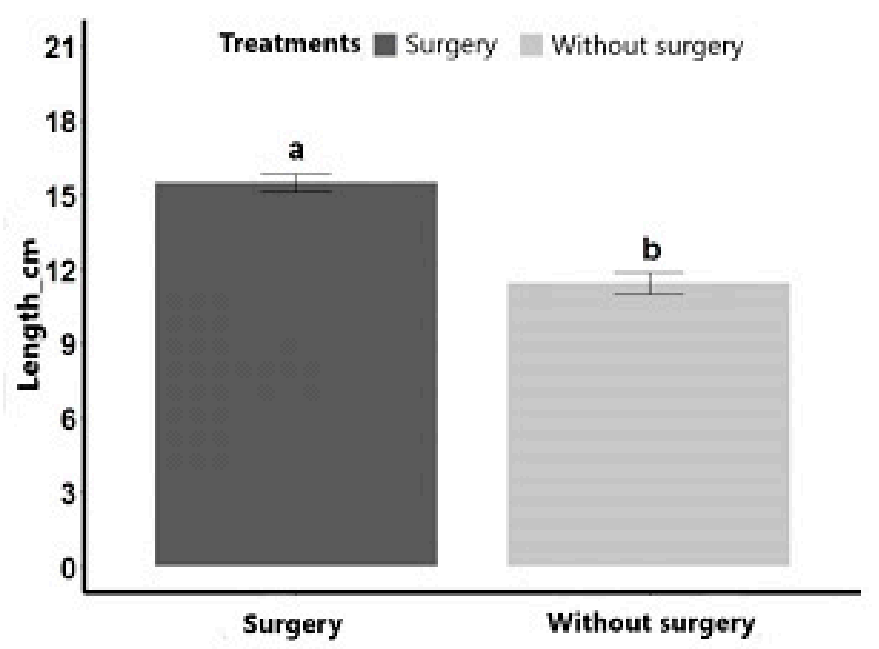

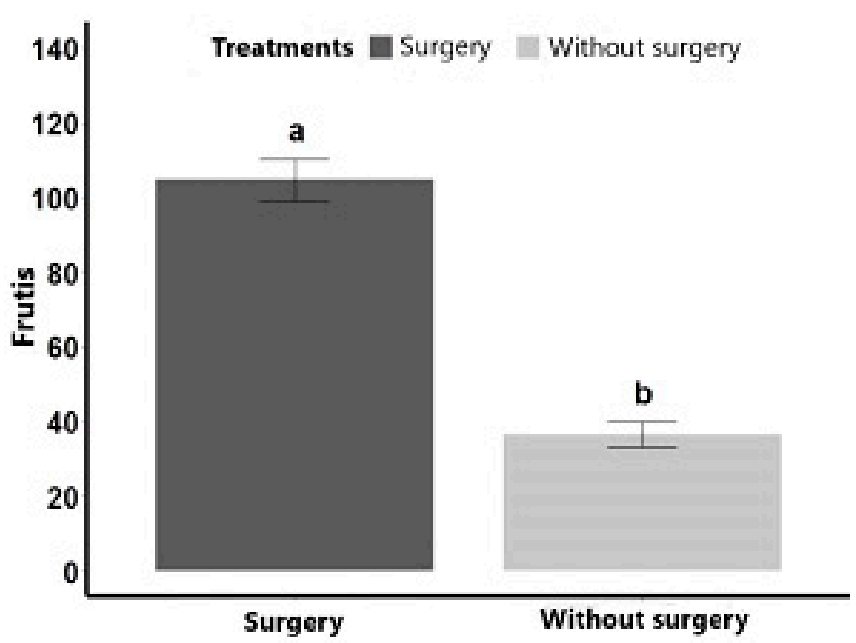

IV

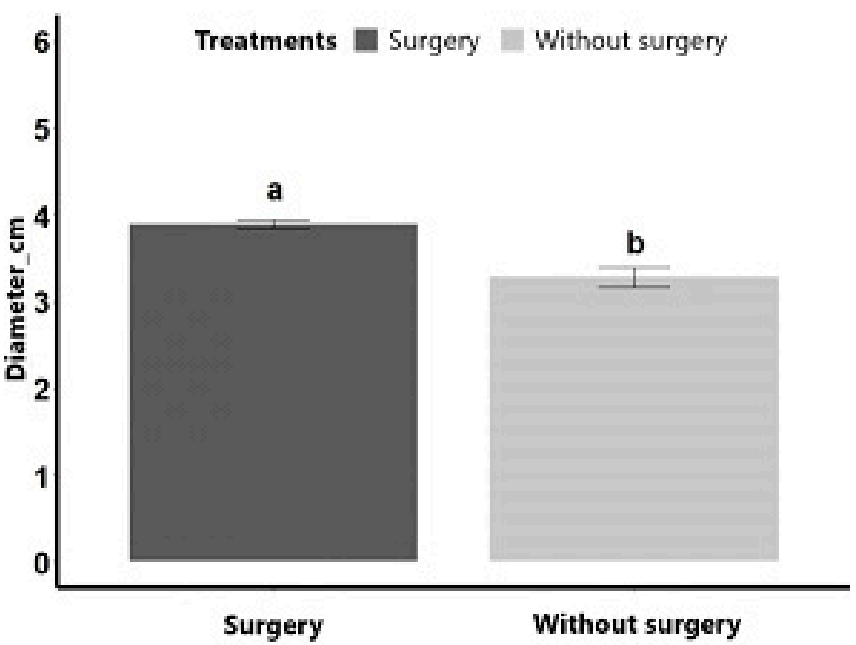

Figure 3. Mean values of treatments (Surgery x Control) on weight (I), number (II), length (III) and diameter (IV) of 'Grande Naine' (Musa acuminata - AAA) banana fruits infected with sigatoka black. Angra dos Reis, RJ. 2016.

\section{Conclusions}

Surgery or surgical defoliation reduced the severity of the disease by up to $58 \%$ and promoted greater number of functional leaves without the presence of black sigatoka symptoms.

Productivity was $300 \%$ higher in plants submitted to defoliation.

\section{Acknowledgments}

To the City Hall of Angra dos Reis and the Secretary of Agriculture for the logistical support in carrying out this research.

To producer Mauricio Portugal Ruopp, owner of the area where the research was carried out.

To the Official Laboratory of Phytosanitary Diagnosis of UFRRJ for the support and financing of this project.

\section{References}

BARRERA, J.; CAYÓN, G.; ROBLES, J. Influencia de la exposición de las hojas y el epicarpio de frutos sobre el desarrollo y la calidad del racimo de plátano 'Hartón' (Musa AAB Simmonds). Agronomía Colombiana, Córdoba, v.27, n.1, p.8, 2008.

BRIOSO, P.S.T.; GASPAROTTO, L. Não ocorrência de Sigatoka Negra de bananeiras oriundas de São Paulo, Brasil. In: CONGRESSO BRASILEIRO DE FITOPATOLOGIA, 45., 2012. Manaus. Anais... p.287. Disponível em: $\leq$ https://www.alice.cnptia.embrapa.br/ alice/bitstream/doc/932887/1/CongFito287.pdf > . Acesso em: 18 out. 2017. 
FAOSTAT. Organização das Nações Unidas para Agricultura e Alimentação. Roma: FAO, 2016. Disponível em: $\leq \mathrm{http}: / /$ www.fao.org/faostat/es/\#data/ QC $>$. Acesso em: 18 dez. 2017.

GASPAROTTO, L.; PEREIRA, J.C.; HANADA, R.E.; MONTARROYOS, A. Sigatoka-negra da bananeira. Métodos de controle. Manaus: Embrapa Amazônia Ocidental, 2006. p.88-123.

GAUHL, F. Epidemiology and ecology of black sigatoka (Mycosphaerella fijiensis) on plantain and banana (Musa spp.) in Costa Rica, Central América. Montpellier: International Network for the Improvementof Banana and Plantain, 1994.

GUZMÁN, M.; ROMERO, R. Determinación del efecto anti-esporulante de diferentes compuestos sobre Mycosphaerella fijiensis. In: CORBANA: Informe anual 1994. San José: Departamento de Investigación y Diversificación Agrícola, 1995. p.46.

IBGE. Produção agrícola municipal 2016. Rio de Janeiro, 2016. Disponível em: $<$ https://cidades.ibge.gov. br/comparamun/compara.php?lang $=\&$ coduf $=33 \&$ idtem $\mathrm{a}=166 \& \operatorname{codv}=\mathrm{V} 57 \&$ order $=$ nome \&dir $=$ desc $\&$ lista $=\mathrm{uf} \& \mathrm{c}$ ustom $=>$. Acesso: 19 out. 2017.

INMET - Instituto Nacional de Meteorologia. Meteograma. Angra dos Reis, 2016. Disponível em: $\leq$ http://www.inmet.gov.br/portal/index.php?r=tempo2/ $\underline{\text { meteograma } \& \text { code }=3300100>}$. Acesso em: 25 maio 2016.

LEHMANN-DANZINGER, H. Planificación de estudios epidemiológicos para prevención y control de Sigatoka Negra en la subregión andina FAO. Roma, 1984. 106 p.

MARTIN, P.; CHARPENTLER. J. M. Symptô m e s de carences en six éléments minéraux Chez le bananier. Fruits, France, v.26, n.3, p.147-221,1963.

MERCHÁN V.M.; CHAVARRIAGA, W.M. Alternativas de manejo de Sigatoka negra en plátano Hartón (Musa AAB). In: REUNIÓN ACORBAT, 11., 1994, Costa Rica. Memorias... p. 325-335.

OROZCO-SANTOS, M. Manejo integrado de la Sigatoka Negra del plátano. Tecomán: SAGAR, INIFAP, CIPAC, 1998. (Folleto Técnico, 1)
OROZCO-SANTOS, M.; FARÍAS-LARIOS, J.; MANZOSÁNCHEZ, G.; GUZMÁN-GONZÁLEZ, S. Manejo integrado de la Sigatoka Negra (Mycosphaerella fijiensis) del banano en el trópico seco de México. In: REUNIÓN ACORBAT, 15., 2002, Cartagena de Indias. Memorias... p. 119-124.

OROZCO-SANTOS, M.; OROZCO, J.; PEREZ, O.; MANZO, G.; FARÍAS, J.; MORAES, W. Prácticas culturales para el manejo de la Sigatoka negra en bananos y plátanos. Tropical Plant Pathology, México. v.33, n.3, p.189-186, 2008.

RODRÍGUEZ A.; CAYÓN, G. Efecto de Mycosphaerella fijiensis sobre la fisiología de la hoja de banano. Agronomía Colombiana, Bogotá. v.26, n.2, p.4, 2008.

RODRÍGUEZ J.A.; IRIZARRY H.; RIVERA E. Efecto de la poda de manos en el rendimiento y calidad de las frutas del plátano (Musa acuminata x Musa balbisiana, $\boldsymbol{A A B}$ ). Medellín: ACORBAT, 1988. p.537- 541.

SILVA, S.O.; ROCHA, S.A.;ALVES, E.J.; CREDICO, M.; PASSOS, A.R. Caracterização morfológica e avaliação de cultivares e híbridos de bananeira. Revista Brasileira de Fruticultura, Jaboticabal, v.22, n.2, p.161-169, 2000.

VILLALTA, R.; GUZMÁN, M. Capacidad de esporulación de Mycosphaerella fijiensis en tejido foliar de banano depositado en el suelo y efecto antiesporulante de la urea. In: CONGRESO CIENTÍFICO TÉCNICO BANANERO NACIONAL, 1., 2005, Pococí, Limón, 2005. p.14.

VILLALTA, R; GUZMÁN, M. Evaluación de prácticas para la reducción de inóculo interno de Mycosphaerella fijiensis. In: CORBANA-Corporación Bananera Nacional. Informe Anual 2005. San José, 2006. p.65-68.

WILKINSON, J.; PEREIRA, P.R.F.; FUNCKE, A.L.; CAMPHORA, A.L.; LATINI, J.L.; LOPANE, A.R.M.; PEDREIRA, B.da C.C.G.; FIDALGO, E.C.C.; PRADO, R.B. Caracterização socioeconômica das bacias hidrográficas dos rios Guapi-Macacu e Caceribu. Rio de Janeiro: Embrapa Solos, 2012. p.160. (Documentos, 149). 